\title{
Modelling and Simulating the Groundwater Level Behavior to Climate Change for the Ozat Basin
}

\author{
A.M. Paghadal ${ }^{\text {* }}$, Prasang H. Rank $^{2}$, H.D. Rank $^{3}$, B.B. Limbasiya ${ }^{4}$, \\ P.B. Vekariya ${ }^{5}$ and H.R. Vadar $^{6}$ \\ ${ }^{1}$ Research Training and Testing Centre, Junagadh Agricultural University, \\ Junagadh - 362001, Gujarat, India \\ ${ }^{2}$ SWCE student, CAET, Junagadh Agricultural University, Junagadh - 362001, Gujarat, India \\ ${ }^{3}$ Soil and Water Conservation Engineering Dept., College of Agricultural Engineering \& \\ Technology, Junagadh Agricultural University, Junagadh \\ ${ }^{4}$ Polytechnic in Agriculture Engineering, JAU, Taghadiya, Rajkot, India \\ ${ }^{5}$ Soil and Water Conservation Engineering Department, College of Agricultural Engineering \\ \& Technology, JAU, Junagadh, India \\ ${ }^{6}$ Polytechnic in Agriculture, JAU, Khapat, Porbandar, India \\ *Corresponding author
}

\begin{tabular}{|l|}
\hline K e y w o r d s \\
Model, Simulation, \\
$\begin{array}{l}\text { Groundwater level, } \\
\text { Climate change }\end{array}$ \\
\hline Article Info \\
\hline $\begin{array}{l}\text { Accepted: } \\
\text { 15 September } 2019 \\
\text { Available Online: } \\
\text { 10 October } 2019\end{array}$ \\
\hline
\end{tabular}

The climate change, its impact assessment, modelling and simulating the groundwater level to climate change were made for the Ozat basin $\left(3176.24 \mathrm{~km}^{2}\right.$ area). The models developed for the sensitivity analysis shows that the wind speed is the most sensitive climatic parameter to the groundwater depletions followed by temperature, solar radiation and relative humidity. The model also indicated that the groundwater depletion is more sensitive to maximum temperature as compared to minimum temperature. The model of the groundwater level depletions response to mean temperature indicates that the increase/decrease in $1{ }^{\circ} \mathrm{C}$ temperature, $1 \mathrm{~m} / \mathrm{s}$ in wind speed and $1 \mathrm{MJ} / \mathrm{sq} . \mathrm{m}$ in solar radiation during winter season in Ozat basin can increase/decrease the $0.422 \mathrm{~m}, 2.14 \mathrm{~m}$ and $0.2325 \mathrm{~m}$ groundwater level depletions respectively while increase/decrease of $1 \%$ in mean relative humidity can decrease/increase $0.154 \mathrm{~m}$ groundwater depletions. The current trend of the climate change indicated that the groundwater depletions will be increasing $0.005 \mathrm{~m}$ per year among which the contribution of the current trend in the wind velocity, mean temperature, mean relative humidity and bright sunshine hours to groundwater depletions can be $-0.00817 \mathrm{~m}, 0.01216 \mathrm{~m},-0.00153 \mathrm{~m}$, and $0.002504 \mathrm{~m}$ per year respectively.

\section{Introduction}

The simulations of groundwater behaviour are very useful for the agricultural resources planning in the region where agriculture depends mainly on the groundwater resources. The groundwater behaviour depends on the aquifer properties, cropping pattern as well as 
climate. As the groundwater being the democratic resources with natural underground flow as per the geo-hydrological characteristics of the aquifer, its behaviour can be studied only on the basin or watershed scale. However, then after, the outputs can be proportionated to the geographical area for any selected region/districts/tehsil/village. The most important and influencing to groundwater behaviour is climate. The climate is changing due to global warming. The only certain is uncertainty in the climate. Therefore, the groundwater behaviour simulation studies for the various climatic parameters are todays need for the sustainable water resources planning on basin scale. So, an effort is made to model the groundwater behaviour response to various climate inputs for the Ozat basin.

\section{Study area}

The study was undertaken for Ozat river basin $\left(3176.24 \mathrm{~km}^{2}\right)$ having 4 watersheds as shown in Figure 1 and 2. The climate of the project area can be classified as tropical and subtropical. It is situated between latitude of $21^{\circ}$ $\mathrm{N}$ to $22^{\circ} \mathrm{N}$ and longitude of $70^{\circ} \mathrm{E}$ to $71^{\circ} \mathrm{E}$. Its length is $125 \mathrm{~km}$ having catchment area of 3176 sq.km. The runoff generated from the Ozat river basin drains to Arabian Sea near Porbandar adjacent to the outlet of Bhadar river basin. The slope of the upper reach of the basin is high with considerable rocked area and forest to some extent. The holy Girnar Mountain is located in upper reach of the basin. The middle reach is having the fine soils having slope of around $1 \%$ and crops adopted are groundnut and cotton during monsoon, wheat, coriander during winter and short duration crops like sesame and groundnut during summer season. The lower reach of the basin is having fine soils with fairly flat slope less than $1 \%$. There is a problem of water flooding in lower reach of basin during monsoon season. The semiwinter crops like sesame, grams and wheat are grown after flood disappears from the field. The climate of the project area can be classified as tropical and sub-tropical. January is the coldest month with mean monthly temperature varying from $4^{\circ} \mathrm{C} \& 15^{\circ} \mathrm{C}$ and maximum monthly temperature varies between $40^{\circ} \mathrm{C}$ and $46^{\circ} \mathrm{C}$ in the month of May. Agriculture is the main occupation in the area. Groundwater is the main source of irrigation in study area.

\section{Materials and Methods}

\section{Date collection}

The water table data records (1969-2010) before and after monsoon for the different gauge stations of the study area with aquifer properties were collected from the Central Groundwater Board, Ahmadabad. The downscaled global climate model simulations (CMIP3) data (1979-2013) namely precipitation, maximum and minimum air temperature, solar radiation, wind speed and relative humidity of total 10 weather grid points $(50 \mathrm{~m} \times 50 \mathrm{~m})$ were used as SWAT inputs as well as for the analysis. The satellite images of SRTM DEM having $90 \mathrm{~m}$ resolution, land use/land cover and soil map were collected from BISAG, Gandhinagar and used in this study.

The seasonal average of the climatic parameters and seasonal groundwater level depletion were estimated. The different types of the models as given in Table-1 were attempted to fit the groundwater level behavior to various climatic parameters. The amount of the groundwater level depletions (GWLD) was estimated using water balance eq. as below.

$$
G W L D=\frac{1}{S}\left\{\sum_{i=1}^{m} K_{a i}\left[\sum_{j=1}^{n}\left(\sum_{k=1}^{l} F_{c c j k}\right)\right]\right\}
$$


Where, GWLD $=$ groundwater level depletion $(\mathrm{m}) ; \mathrm{K}_{\mathrm{a}}=\mathrm{A}_{\mathrm{gwi}} / \mathrm{A}=$ ratio of area irrigated from groundwater resources $\left(\mathrm{A}_{\mathrm{gwi}}\right)$ during $\mathrm{i}^{\text {th }}$ season to total geographical area(A) of the basin; $\mathrm{K}_{\mathrm{cjk}}=$ crop coefficient of $\mathrm{j}^{\text {th }}$ crop during $\mathrm{k}^{\text {th }}$ growing stage in the basin; $\mathrm{S}=$ storativity of the aquifer; $\mathrm{W}=$ wind $\operatorname{speed}(\mathrm{kmph}) ; \quad \mathrm{F}_{\mathrm{ccjk}}=\mathrm{f}_{\mathrm{n}}($ Crop, Climate $)=$ $\mathrm{f}_{\mathrm{n}}\left(\mathrm{K}_{\mathrm{cjk}}, \mathrm{ET}_{\text {oik }}\right), \mathrm{ET}_{\text {oik }}=\mathrm{f}\left(\mathrm{W}, \mathrm{T}_{\max }, \mathrm{T}_{\min }, \mathrm{RH}\right.$, $\mathrm{SR})=$ reference $\mathrm{crop}$ evapotranspiration $(\mathrm{m})$ during $\mathrm{k}^{\text {th }}$ growing stage of $\mathrm{i}^{\text {th }}$ season; $\mathrm{T}_{\max }=$ daily maximum temperature $\left({ }^{\circ} \mathrm{C}\right) ; \mathrm{T}_{\min }=$ daily minimum temperature $\left({ }^{\circ} \mathrm{C}\right) ; \mathrm{RH}_{\text {mean }}=$ daily mean relative humidity $(\%)$; $\mathrm{SR}=$ Solar radiation(KJ/sq.m). i, j, k= an index for the season, crop and growing stage respectively. $\mathrm{m}, \mathrm{n}$ and $\mathrm{l}=$ total number of seasons, crops and growing stages. In the basin area, the irrigated area from the groundwater resources was taken into account and the factor $\mathrm{K}_{\mathrm{ai}}$ was taken as 0.4 for the winter season. The cropping period $(\mathrm{N})$ and crop coefficient $\left(\mathrm{K}_{\mathrm{c}}\right)$ were taken as an average of 0.8 and 120 days respectively for the cropping pattern adopted by the farmers. The reference evapotranspiration $\left(\mathrm{ET}_{0}\right)$ was determined using FAO-56 method at daily time scale for the various climatic inputs. The storativity of the aquifer of the basin was taken as 0.015 .

\section{Results and Discussion}

The developed models which were found best fit are given in Table-1.

\section{Additive linear models}

The developed additive liner models (Eqn. 1 to 6) and additive nonlinear models (Eqn. 7-8) are given in Table-1. The additive models stated as eqn. 1 to 4 are found quite reasonable for simulating the groundwater behavior when only either of seasonal average of daily mean temperature (Eqn 1a), minimum temperature (Eqn 1b), maximum temperature (Eqn 1c), daily mean relative humidity (Eqn 2 ), wind speed (Eqn 3) and solar radiation (Een. 4) is changed due to climate change while the rest of climatic parameters are unchanged. The additive models for groundwater behavior response to climatic parameters like wind speed, temperature, relative humidity and bright sunshine hours were also developed and found as stated as Eqn. 5-6. These additive linear models (Eqn.5-6) were found fitted well having good $\mathrm{R}^{2}$ values.

\section{Additive nonlinear models}

These additive models (Eqn. 7-8) did not seem realistic. The model given as Eqn 7 shows that the power exponent of the mean temperature is negative and too high indicating that the contributions of temperature for the groundwater depletion is negligible which is not the reality. In the model Eqn. 8, the multiplying coefficient is negative while the power exponents of minimum temperature are positive indicating unrealistic effects of minimum temperature on groundwater depletions.

\section{Nonlinear models}

The nonlinear models of power form stated as Eqn. 9-12 are found more accurate than additive models (eqn. 1-4) for simulating the groundwater behavior. Similar to additive models, these models also can be used when only either of seasonal average of daily mean temperature (Eqn 9a), minimum temperature (Eqn 9b), maximum temperature (Eqn 9c), daily mean relative humidity (Eqn 10), wind speed (Eqn 11) or solar radiation(Eqn. 12) is affected by the climate change but not the rest.

\section{Nonlinear multiplicative models}

The multiplicative models for groundwater behavior response to climatic parameters like wind speed, temperature, relative humidity and solar radiation were also developed and 
found as stated as Eqn. 13-14. The multiplicative model as Eqn 13 is handy and can require only seasonal average of daily mean temperature, relative humidity, wind speed and bright sunshine hours. The multiplicative model given as Eqn. 14 can predict more accurately the groundwater level behavior under various climate change scenarios. It requires the seasonal average of daily wind speed, minimum temperature, maximum temperature, mean relative humidity, and bright sunshine hours.

Simulation of the groundwater level fluctuation with respect to warming trend

It could be seen that both the relationships i .e. linear and power form was found fit with good $\mathrm{R}^{2}$. The linear model (Eqn 1a) showed that the increase/decrease in $1{ }^{\circ} \mathrm{C}$ temperature can increase/decrease the $0.422 \mathrm{~m}$ groundwater level depletion. The power form of model (Eqn.9a) also supported the same. The linear models as stated as eqn. $1 \mathrm{~b} \& 1 \mathrm{c}$ shows that for increase/decrease of $1{ }^{\circ} \mathrm{C}$ in seasonal average of daily minimum temperature and maximum temperature can increase/decrease $0.065 \mathrm{~m}$ and $0.35 \mathrm{~m}$ groundwater level depletion respectively. The comparative simulation of $T_{\max }$ and $T_{\min }$ shows that the effect of $T_{\max }$ is higher than $\mathrm{T}_{\min }$ on the groundwater level depletion. Also their effects on groundwater depletion is decreasing with their values are increased.

\section{Simulation of groundwater level fluctuation with relative humidity}

The model for the groundwater level depletion in response to relative humidity was developed (Eqn $2 \& 10$ ). The other parameters were assumed to be at present average values. The both forms of the model viz. linear (Eqn 2) and power form (10) for the groundwater level depletions response to relative humidity were found fit $\left(\mathrm{R}^{2}=0.99\right)$. The linear model
(Eqn.2) of the groundwater level depletions response to mean relative humidity shows that the groundwater level depletion will be reduced/increased by the tune of $0.154 \mathrm{~m}$ for every increase/decrease of $1 \%$ mean relative humidity. The power form of the model also supported the results. However, the effect of change in relative humidity on the groundwater level depletions is decreasing with increase in level of the relative humidity $(\%)$.

\section{Simulation of groundwater level fluctuation with temperature and relative humidity}

The groundwater behavior response to temperature and relative humidity was studied using eqn (13). It could be seen that the effects of temperature on groundwater depletion is higher under lower humidity as compared to that of higher humidity.

\section{Simulation of groundwater level fluctuation with wind speed}

The groundwater behavior response to possible change in wind speed due to climate change was studied. The linear model (eqn. 3) shows that there can be $2.14 \mathrm{~m}$ increase/decrease of groundwater level depletions with increase/decrease of $1 \mathrm{kmph}$ in wind speed. The power form (Eqn. 11) also supported the same results. The power form of model indicated that the effects of change in wind speed decreased with increased level of wind speed.

\section{Simulation of groundwater level fluctuation with climatic}

The additive liner (Eqn. 5-6), additive nonlinear(Eqn. 7-8) and Nonlinear multiplicative (Eqn. 13-14) models for groundwater behavior response to climatic parameters like wind speed, temperature, relative humidity and bright sunshine hours 
can be used for the simulation. The additive nonlinear models (Eqn. 7-8) did not seem realistic even though having reasonable $R^{2}$ values. Therefore, the additive models (Eqn. 7-8) were not considered for the simulations of the groundwater behavior.

The multiplicative models (Eqn. $13 \& 15$ ) show that wind speed is the most influencing climatic parameter to the groundwater depletions followed by temperature, solar radiation and relative humidity. The model (Eqn.14 \& 16) also indicated that the groundwater depletion is influenced more by maximum temperature as compared to that of minimum temperature.

\section{Simulation of groundwater level fluctuation with current climatic change trend}

The current climate change trend of the different climactic parameters (Table-2) was taken into account and the simulation of the groundwater level behavior to climate change was studied. The developed multiplicative models (Eqn. 13 \& 14) were differentiated partially with respects to year and following models (Eqn. $15 \& 16$ ) for the simulations of the impacts of the current climate change trend on the groundwater level behavior were developed.

$$
\begin{aligned}
& \frac{\partial G W L D}{\partial t}=K_{1} \frac{\partial W}{\partial t}+K_{2} \frac{\partial T_{\text {maan }}}{\partial t}+K_{3} \frac{\partial R H_{\text {mean }}}{\partial t}+K_{4} \frac{\partial S R}{\partial t} \ldots(15) \\
& \frac{\partial G W L D}{\partial t}=2.0418 \frac{\partial W}{\partial t}+0.40534 \frac{\partial T_{\text {maan }}}{\partial t}-0.153 \frac{R H_{\text {mean }}}{\partial t}+0.2504 \frac{\partial S R}{\partial t}
\end{aligned}
$$

Where, the variables of the climatic parameters are as defined earlier. $\mathrm{K}_{\mathrm{i}}$ are the multiplying coefficients having derived values as $\mathrm{K}_{1}=2.0418 ; \mathrm{K}_{2}=0.40534 ; \mathrm{K}_{3}=-0.153$; and $\mathrm{K}_{4}=0.25038$.

$\frac{\partial G W L D}{\partial t}=K_{1} \frac{\partial W}{\partial t}+K_{2} \frac{\partial T_{\max }}{\partial t}+K_{3} \frac{\partial T_{\min }}{\partial t}+K_{4} \frac{\partial R H_{\operatorname{man}}}{\partial t}+K_{6} \frac{\partial S R}{\partial t}$ $\frac{\partial G W L D}{\partial t}=2.14925 \frac{\partial W}{\partial t}+0.3345 \frac{\partial T_{\max }}{\partial t}+0.07059 \frac{\partial T_{\min }}{\partial t}-0.1332 \frac{\partial R H_{\text {mean }}}{\partial t}$ $+0.15574 \frac{\partial S R}{\partial t}$

Where, the variables of the climatic parameters are as defined earlier. $\mathrm{Ki}$ are the multiplying coefficients having derived values as $\mathrm{K}_{1}=2.14925 ; \mathrm{K}_{2}=0.3345 ; \mathrm{K}_{3}=0.07059 ; \mathrm{K}_{4}$ $=-0.1332$; and $\mathrm{K}_{5}=0.15574$.

The current trend of different climatic parameters under climate change is presented in Table- 2. The current trend of the climate was used to assess the climate change impacts on the groundwater level behavior using the models as stated by eqn. 15 and 16. The current trend of the climate change indicated that the groundwater depletions will be increasing $0.005 \mathrm{~m}$ per year among which the contribution of the current trend in the wind velocity, mean temperature, mean relative humidity and bright sunshine hours to groundwater depletions can be $-0.00817 \mathrm{~m}$, $0.01216 \mathrm{~m},-0.00153 \mathrm{~m}$, and $0.002504 \mathrm{~m}$ per year respectively (Eqn. 15). The developed model (Eqn 16) shows that wind velocity is more responsible to groundwater depletions followed by maximum temperature, minimum temperature, solar radiations and mean relative humidity. The current trend of climate change impacts on the groundwater depletion can be increase of $0.004 \mathrm{~m}$ per year among which the contributions of the wind velocity, maximum \& minimum temperature, mean relative humidity and solar radiation to groundwater depletion can be $-0.0086 \mathrm{~m}, 0.010035 \mathrm{~m}$, $0.002118 \mathrm{~m},-0.00113 \mathrm{~m}$ and $0.001557 \mathrm{~m}$ per year respectively in the Ozat basin.

In conclusion, the following models are found most suitable and fit to simulate the groundwater level behavior response to climate for the Ozat basin.

$$
\begin{aligned}
& \mathrm{GWLD}=\left[1.672(\mathrm{~W})^{0.460}\left(\mathrm{~T}_{\text {mean }}\right)^{0.691}\left(\mathrm{RH}_{\text {mean }}\right)\right. \\
& \left.{ }^{0.409}(\mathrm{SR})^{0.309}\right]
\end{aligned}
$$


Table.1 Developed best fit models for groundwater level response to climate

\begin{tabular}{|c|c|c|}
\hline SN & Best fit Model & Eqn. \\
\hline A & \multicolumn{2}{|l|}{ Additive Linear model } \\
\hline 1 & $\begin{array}{l}\text { GWLD }=0.422 \mathrm{~T}_{\text {mean }}+4.23 \quad\left(\mathrm{R}^{2}=0.99\right) \\
\mathrm{GWLD}=0.353 \mathrm{~T}_{\max }+3.47 \quad\left(\mathrm{R}^{2}=0.99\right) \\
\mathrm{GWLD}=0.065 \mathrm{~T}_{\min }+13.7 \quad\left(\mathrm{R}^{2}=0.99\right)\end{array}$ & $\begin{array}{l}\text { (1a) } \\
(1 b) \\
(1 c)\end{array}$ \\
\hline 2 & GWLD $=-0.154($ RHmean $)+20.948\left(R^{2}=0.99\right)$ & (2) \\
\hline 3 & GWLD $=2.14(\mathrm{~W})+7.728\left(\mathrm{R}^{2}=0.99\right)$ & $(3)$ \\
\hline 4 & $\mathrm{GWLD}=0.2325(\mathrm{SR})+10.619\left(\mathrm{R}^{2}=0.99\right)$ & $(4)$ \\
\hline 5 & $\mathrm{GWLD}=\left[2.14(\mathrm{~W})+0.422\left(\mathrm{~T}_{\text {mean }}\right)-0.154\left(\mathrm{RH}_{\text {mean }}\right)+0.233(\mathrm{SR})-1.128\right] \quad\left(\mathrm{R}^{2}=0.99\right)$ & $(5)$ \\
\hline 6 & $\begin{array}{l}\mathrm{GWLD}=\left[2.2541(\mathrm{~W})+0.353\left(\mathrm{~T}_{\max }\right)+0.065\left(\mathrm{~T}_{\min }\right)-0.132\left(\mathrm{RH}_{\text {mean }}\right)+0.133(\mathrm{SR})-2.460\right] \\
\left(\mathrm{R}^{2}=0.99\right)\end{array}$ & (6) \\
\hline $\mathbf{B}$ & \multicolumn{2}{|l|}{ Additive Nonlinear model } \\
\hline 7 & $\begin{array}{l}\mathrm{GWLD}=\left[-2377.4(\mathrm{~W})^{-900.68}+74874.4\left(\mathrm{~T}_{\text {mean }}\right)^{-15872.2}-6.2 \mathrm{E}-03\left(\mathrm{RH}_{\text {mean }}\right)^{-49.3075}-65.6(\mathrm{SR})^{-}\right. \\
\left.{ }^{-} 8.9+14.9\right]\left(\mathrm{R}^{2}=-2.22 \mathrm{E}-16\right)\end{array}$ & $(7)$ \\
\hline 8 & $\begin{array}{l}\text { GWLD }=\left[-18069.3(\mathrm{~W})^{-31278.9}+0.039\left(\mathrm{~T}_{\max }\right)^{1.77}-5.00\left(\mathrm{~T}_{\min }\right)^{0.55}+0.027\left(\mathrm{RH}_{\text {mean }}\right)\right. \\
\left.-3.29+3.44(\mathrm{SR})^{0.25}+14.15\right]\left(\mathrm{R}^{2}=0.51\right)\end{array}$ & (8) \\
\hline C & \multicolumn{2}{|l|}{ Nonlinear models } \\
\hline 9 & $\begin{array}{l}\text { GWLD }=01.594\left(\mathrm{~T}_{\text {mean }}\right)^{0.691} \quad\left(\mathrm{R}^{2}=0.99\right) \\
\text { GWLD }=11.533\left(\mathrm{~T}_{\text {min }}\right)^{0.087}\left(\mathrm{R}^{2}=0.99\right) \\
\text { GWLD }=01.182\left(\mathrm{~T}_{\max }\right)^{0.728} \quad\left(\mathrm{R}^{2}=0.99\right)\end{array}$ & $\begin{array}{l}(9 a) \\
(9 b) \\
(9 c)\end{array}$ \\
\hline 10 & GWLD $=66.665\left(\mathrm{RH}_{\text {mean }}\right)^{-0.409}\left(\mathrm{R}^{2}=0.99\right)$ & (10) \\
\hline 11 & GWLD $=8.527(\mathrm{~W})^{0.460} \quad\left(\mathrm{R}^{2}=0.99\right)$ & (11) \\
\hline 12 & $\mathrm{GWLD}=6.046(\mathrm{SR})^{0.309}\left(\mathrm{R}^{2}=0.99\right)$ & $(12)$ \\
\hline $\mathbf{D}$ & \multicolumn{2}{|l|}{ Nonlinear Multiplicative models } \\
\hline 13 & $\mathrm{GWLD}=\left[1.672(\mathrm{~W})^{0.460}\left(\mathrm{~T}_{\text {mean }}\right)^{0.691}\left(\mathrm{RH}_{\text {mean }}\right)^{-0.409}(\mathrm{SR})^{0.309}\right]\left(\mathrm{R}^{2}=0.99\right)$ & (13) \\
\hline 14 & $\mathrm{GWLD}=\left[1.072(\mathrm{~W})^{0.485}\left(\mathrm{~T}_{\max }\right)^{0.728}\left(\mathrm{~T}_{\min }\right)^{0.087}\left(\mathrm{RH}_{\text {mean }}\right)^{-0.355}(\mathrm{SR})^{0.193}\right]\left(\mathrm{R}^{2}=0.99\right)$ & $(14)$ \\
\hline \multicolumn{3}{|c|}{$\begin{array}{l}\text { Where, GWLD= groundwater level depletion }(\mathrm{m}) ; \mathrm{T}_{\text {mean }}=\text { seasonal average daily mean } \\
\text { temperature }\left({ }^{\circ} \mathrm{C}\right) ; \mathrm{T}_{\min }=\text { seasonal average of daily minimum temperature }\left({ }^{\circ} \mathrm{C}\right) ; \mathrm{T}_{\max }= \\
\text { seasonal average of daily maximum temperature }\left({ }^{\circ} \mathrm{C}\right) ; \mathrm{RH}_{\text {mean }}=\text { seasonal average daily } \\
\text { mean relative humidity }(\%) ; \mathrm{W}=\text { seasonal average wind speed }(\mathrm{m} / \mathrm{s}) ; \mathrm{SR}=\text { seasonal average } \\
\text { daily solar radiation }(\mathrm{MJ} / \mathrm{sq} . \mathrm{m}) . \mathrm{C}, \mathrm{k}_{\mathrm{i}} \text { and } \mathbf{a}_{\mathrm{i}} \text { are the empirical coefficient. }\end{array}$} \\
\hline
\end{tabular}


Table.2 The current climate change trend of the different climactic parameters

\begin{tabular}{|c|c|c|c|c|c|c|c|}
\hline \multirow{2}{*}{$\begin{array}{l}\text { Sr. } \\
\text { No. }\end{array}$} & \multicolumn{2}{|l|}{ Parameter } & \multirow[t]{2}{*}{ Unit } & \multicolumn{4}{|c|}{ Periods } \\
\hline & & & & Winter & Summer & Monsoon & Annual \\
\hline & \multirow{2}{*}{$\begin{array}{l}\text { Daily maximum } \\
\text { temperature- } \mathrm{T}_{\max }\end{array}$} & Mean & ${ }^{0} \mathrm{C}$ & 32.32 & 36.87 & 31.68 & 33.62 \\
\hline & & Trend & ${ }^{0} \mathrm{C} /$ year & $0.03 * *$ & $0.02 \mathrm{NS}$ & $-0.01 \mathrm{NS}$ & $0.01 *$ \\
\hline \multirow[t]{2}{*}{2} & \multirow{2}{*}{$\begin{array}{l}\text { Daily minimum } \\
\text { temperature- } T_{\min }\end{array}$} & Mean & ${ }^{0} \mathrm{C}$ & 18.24 & 22.21 & 25.32 & 21.92 \\
\hline & & Trend & ${ }^{0} \mathrm{C} /$ year & $0.03 * * *$ & $0.03 * * * *$ & $0.02 * * *$ & $0.03 * * * *$ \\
\hline \multirow[t]{2}{*}{3} & \multirow{2}{*}{$\begin{array}{l}\text { Daily mean temperature- } \\
\mathrm{T}_{\text {mean }}\end{array}$} & Mean & ${ }^{0} \mathrm{C}$ & 23.23 & 27.32 & 27.50 & 26.02 \\
\hline & & Trend & ${ }^{0} \mathrm{C} /$ year & $0.03 * * *$ & $0.02 * * *$ & $0.01 *$ & $0.02 * * *$ \\
\hline \multirow[t]{2}{*}{4} & \multirow{2}{*}{$\begin{array}{l}\text { Daily maximum relative } \\
\text { humidity- } \mathrm{RH}_{\text {mean }}\end{array}$} & Mean & $\%$ & 39.40 & 49.76 & 76.46 & 55.21 \\
\hline & & Trend & $\% / y e a r$ & $0.01 \mathrm{NS}$ & $-0.02 \mathrm{NS}$ & $0.12 * *$ & $0.03 \mathrm{NS}$ \\
\hline \multirow[t]{2}{*}{5} & \multirow[t]{2}{*}{ Wind velocity-W } & Mean & $\mathrm{m} / \mathrm{s}$ & 3.34 & 4.22 & 4.12 & 3.89 \\
\hline & & Trend & $\mathrm{m} / \mathrm{s} /$ year & $-0.004 N S$ & $0.002 \mathrm{NS}$ & $-0.003 \mathrm{NS}$ & $-0.002 \mathrm{NS}$ \\
\hline \multirow[t]{2}{*}{6} & \multirow[t]{2}{*}{ Daily solar radiation-SR } & Mean & $\mathrm{MJ} / \mathrm{Sq} \mathrm{m}$ & 18.34 & 24.92 & 16.57 & 19.94 \\
\hline & & Trend & $\begin{array}{l}\mathrm{MJ} / \mathrm{Sq} \mathrm{m} / \\
\text { year }\end{array}$ & $0.01 \mathrm{NS}$ & $-0.01 N S$ & $0.02^{*}$ & $0.01 \mathrm{NS}$ \\
\hline \multirow[t]{2}{*}{7} & \multirow{2}{*}{ Seasonal rainfall-RF } & Mean & $\mathrm{mm}$ & - & - & 967.53 & - \\
\hline & & Trend & $\begin{array}{l}\mathrm{mm} / \\
\text { year }\end{array}$ & - & - & $14.52^{* * *}$ & - \\
\hline \multirow[t]{2}{*}{8} & \multirow{2}{*}{$\begin{array}{l}\text { Seasonal runoff-RO by } \\
\text { SCS-CN }\end{array}$} & Mean & $\mathrm{mm}$ & - & - & 225.07 & - \\
\hline & & Trend & $\begin{array}{l}\mathrm{mm} / \\
\text { year }\end{array}$ & - & - & $4.66^{* *}$ & - \\
\hline \multirow[t]{2}{*}{9} & \multirow{2}{*}{$\begin{array}{l}\text { Seasonal runoff-RO by } \\
\text { SWAT }\end{array}$} & Mean & $\mathrm{mm}$ & - & - & 170 & \\
\hline & & Trend & $\begin{array}{l}\mathrm{mm} / \\
\text { year }\end{array}$ & - & - & $4.31^{* *}$ & - \\
\hline \multirow[t]{2}{*}{10} & \multirow{2}{*}{$\begin{array}{l}\text { Seasonal reference } \\
\text { evapotranspiration-ETo }\end{array}$} & Mean & $\mathrm{mm}$ & 721.13 & 939.20 & 539.97 & 2200.90 \\
\hline & & Trend & $\begin{array}{l}\mathrm{mm} / \\
\text { year }\end{array}$ & $0.34 \mathrm{NS}$ & $0.52^{*}$ & $-0.69 \mathrm{NS}$ & $0.16^{*}$ \\
\hline \multirow[t]{2}{*}{11} & \multirow{2}{*}{$\begin{array}{l}\text { Seasonal reference } \\
\text { evapotranspiration-ETo } \\
\text { by SWAT }\end{array}$} & Mean & $\mathrm{mm}$ & - & - & 663 & - \\
\hline & & Trend & $\begin{array}{l}\mathrm{mm} / \\
\text { year }\end{array}$ & - & - & $-1.46 \mathrm{NS}$ & - \\
\hline \multirow[t]{2}{*}{12} & \multirow{2}{*}{$\begin{array}{l}\text { Seasonal groundwater } \\
\text { recharge by Krishna Rao } \\
\text { method }\end{array}$} & Mean & $\mathrm{mm}$ & - & - & 143.9 & - \\
\hline & & Trend & $\begin{array}{l}\mathrm{mm} / \\
\text { year }\end{array}$ & - & - & $3.76^{* *}$ & - \\
\hline \multirow[t]{2}{*}{13} & Seasonal groundwater & Mean & $\mathrm{mm}$ & - & - & 61.26 & - \\
\hline & $\begin{array}{l}\text { recharge by water table } \\
\text { fluctuation method }\end{array}$ & Trend & $\begin{array}{l}\mathrm{mm} / \\
\text { year }\end{array}$ & - & - & $0.03 \mathrm{NS}$ & - \\
\hline 14 & Seasonal groundwater & Mean & $\mathrm{mm}$ & - & - & 163 & - \\
\hline & res & Trend & $\begin{array}{l}\mathrm{mm} / \\
\text { year }\end{array}$ & - & - & $4.46^{* 3 *}$ & - \\
\hline 15 & Groundwater level & Mean & $\mathrm{m}$ & - & - & 6.13 & - \\
\hline & fluctuations & Trend & $\mathrm{m} /$ year & - & - & $0.03 \mathrm{NS}$ & - \\
\hline & $* * * *, * * *, * *$, and $*$ & ignifi & at $0.1 \%$ & $5 \%$ & & 1 & \\
\hline
\end{tabular}


Int.J.Curr.Microbiol.App.Sci (2019) 8(10): 1156-1165

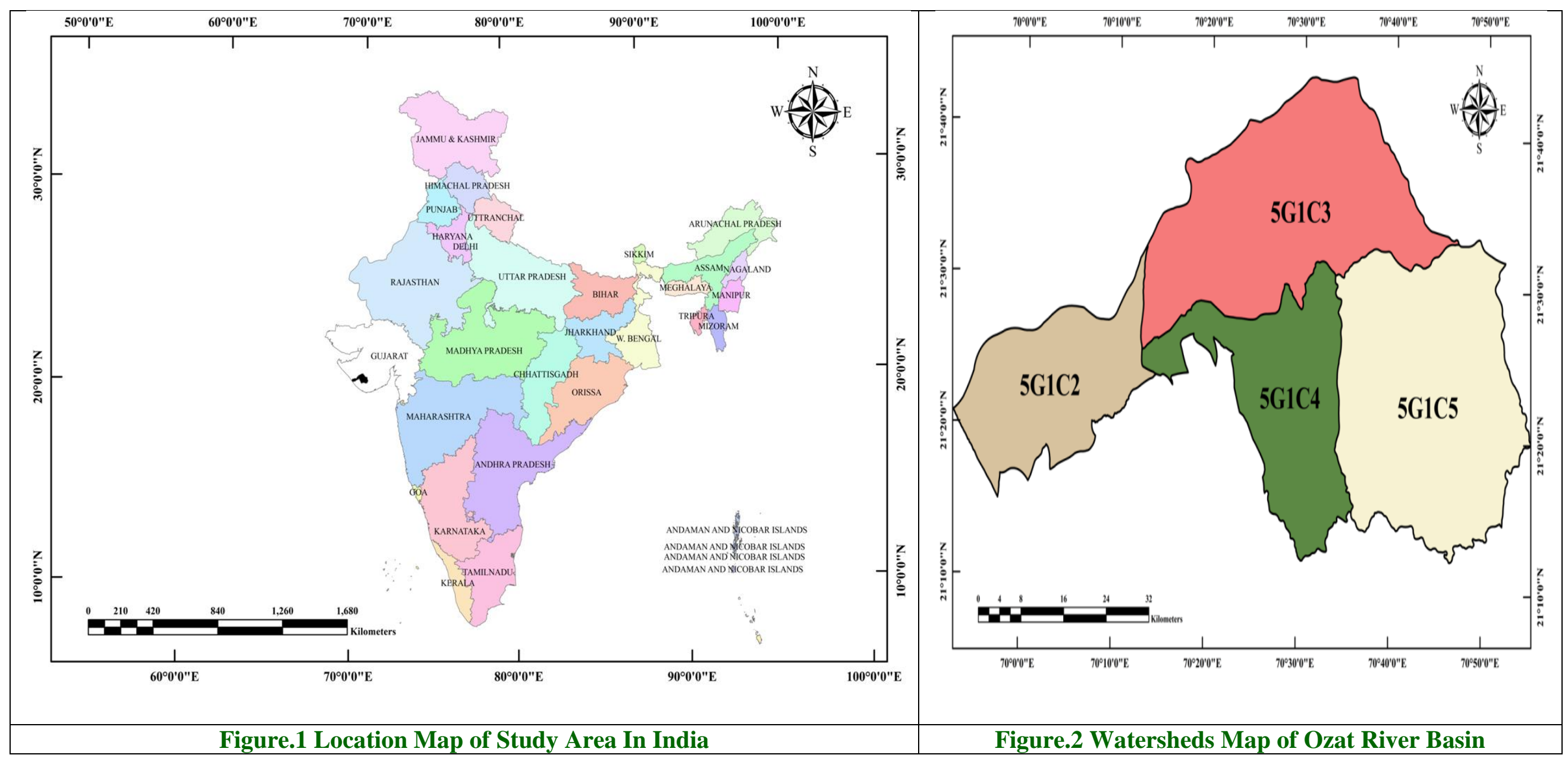




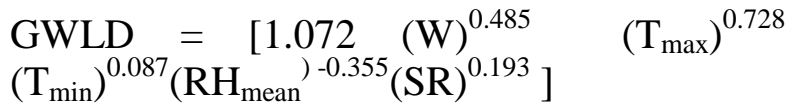

Where, GWLD = groundwater level depletion(m);

$\mathrm{W}=$ Seasonal average wind $\operatorname{speed}(\mathrm{m} / \mathrm{s})$;

$\mathrm{T}_{\max }=$ Seasonal average daily maximum temperature $\left({ }^{\circ} \mathrm{C}\right)$;

$\mathrm{T}_{\min }=$ Seasonal average daily minimum temperature $\left({ }^{\circ} \mathrm{C}\right)$;

$\mathrm{T}_{\text {mean }}=$ Seasonal average daily mean temperature $\left({ }^{\circ} \mathrm{C}\right)$;

$\mathrm{RH}_{\text {mean }}=$ Seasonal average of daily mean relative humidity $(\%)$;

$\mathrm{SR}=$ Seasonal average solar radiation(MJ/sq.m).

The following models were developed for the sensitivity analysis in the simulation of the groundwater level behavior to climate.

$\frac{\partial G W L D}{\partial t}=2.0418 \frac{\partial W}{\partial t}+0.40534 \frac{\partial T_{\text {maan }}}{\partial t}-0.153 \frac{R H_{\text {mean }}}{\partial t}+0.2504 \frac{\partial S R}{\partial t}$

$\frac{\partial G W L D}{\partial t}=2.14925 \frac{\partial W}{\partial t}+0.3345 \frac{\partial T_{\max }}{\partial t}+0.07059 \frac{\partial T_{\min }}{\partial t}-0.1332 \frac{\partial R H_{\operatorname{man}}}{\partial t}$ $+0.15574 \frac{\partial S R}{\partial t}$

Where, the variables of the climatic parameters are as defined earlier.

The models developed for the sensitivity analysis (Eqn. 15 and 16) shows that the wind speed is the most sensitive climatic parameter to the groundwater depletions followed by temperature, solar radiation and relative humidity. The model (Eqn.16) also indicated that the groundwater depletion is more sensitive to maximum temperature as compared to minimum temperature.

The model of the groundwater level depletions response to mean temperature indicates that the increase/decrease in $1{ }^{\circ} \mathrm{C}$ temperature, $1 \mathrm{~m} / \mathrm{s}$ in wind speed and 1
$\mathrm{MJ} / \mathrm{sq} . \mathrm{m}$ in solar radiation during winter season in Ozat basin can increase/decrease the $0.422 \mathrm{~m}, 2.14 \mathrm{~m}$ and $0.2325 \mathrm{~m}$ groundwater level depletions respectively while increase/decrease of $1 \%$ in mean relative humidity can decrease/increase $0.154 \mathrm{~m}$ groundwater depletions.

\section{Simulation of groundwater level behavior to current climate change}

The current trend of the climate change indicated that the groundwater depletions will be increasing $0.005 \mathrm{~m}$ per year among which the contribution of the current trend in the wind velocity, mean temperature, mean relative humidity and bright sunshine hours to groundwater depletions can be $-0.00817 \mathrm{~m}$, $0.01216 \mathrm{~m},-0.00153 \mathrm{~m}$, and $0.002504 \mathrm{~m}$ per year respectively.

\section{Acknowledgements}

The authors are grateful to the Directorate of Water Management, ICAR, Bhubaneswar for the financial and technical supports for the study under NICRA project. The authors are also thankful to SWDC, Gandhinagar, CGWB, Ahmedabad and BISAG, Gandhinagar for providing the required data in this study.

\section{References}

Allen RG, Pereira LSD, Raes, Smith M. Crop evapotranspiration. Guidelines for computing crop water requirements. FAO Irrigation and drainage paper 56. 1998; FAO, UN.

Bandyopadhyay A, Bhadra A, Raghuwanshi NS, and Singh R. Temporal trends in estimates of reference evapotranspiration over India. J. Hydrologic Engg., 2009; 145:508-515.

Brauner JS. Nonparametric estimation of slope-Sen's method. In 
"Environmental sampling and monitoring primer". 1997; (Eds. Gallagher and Daniel). (online at URL http://www.cee.vt.edu).

Brutsaert WY, Parlange MB. Hydrologic cycle explained the evaporation paradox Nature. 1998; 30:396.

Gilbert RO. "Statistical methods for environmental pollution monitoring" 1987; (Van Nostrand Reinhold, NY).

Gosain AK, Rao S, and Basuray, D. Climate change impact assessment on hydrology of Indian River basins. Current Sci. 2006; 90(3).

Hingane LS, Rupakumar K., Ramamurty BV. Long term trends of surface air temperature in India. J.Climatology; 1985; 5: 521-528.
Kendall M and Gibbons JD. Rank Correlation Methods. $5^{\text {th }}$ Eds.(Oxford University Press, NY).1990.pp: 272.

Liu B, Xu M, Henderson M and Gong W. A spatial analysis of pan evaporation trends in China. 1965-2000, J. Geophys. Res. 2004; 109(10):1029.

Roderick ML and Farquhar GD. Changes in Australian pan evaporation from 1970 to 2002. Int. J. Climatol. 2004; 24:107790.

Thomas A. Spatial and temporal characteristics of potential evapotranspiration trend over china. Int. J. Climatol., 2004; 20: 381-96.

\section{How to cite this article:}

Paghadal, A.M., Prasang H. Rank, H.D. Rank, B.B. Limbasiya, P.B. Vekariya and Vadar, H.R. 2019. Modelling and Simulating the Groundwater Level Behavior to Climate Change for the Ozat Basin. Int.J.Curr.Microbiol.App.Sci. 8(10): 1156-1165.

doi: https://doi.org/10.20546/ijcmas.2019.810.135 